\title{
SUMPAH PEMUDA ARAB, 1934: PERGULATAN IDENTITAS ORANG ARAB-HADRAMI DI INDONESIA
}

\author{
Rabith Jihan Amaruli, Nazala Noor Maulany, Singgih Tri Sulistiyono \\ Departemen Sejarah, Fakultas Ilmu Budaya, \\ Universitas Diponegoro, Semarang-Indonesia
}

Alamat korespondensi: rjamaruli@live.undip.ac.id

Diterima/ Received: 2 Agustus 2018; Disetujui/ Accepted: 31 Agustus 2018

\begin{abstract}
This article discusses the Sumpah Pemuda Arab (Arab Youth Pledge) in 1934 which became the forerunner of the formation of the first Arab-Hadrami nationalist organization, the Arab Association of Indonesia (PAI) which later became the Arab Party of Indonesia (PAI). This article conducted by using the historical method. Sumpah Pemuda Arab 1934 is the answer to the struggle of Arab-Hadrami identity and nationalism to fulfill its right as part of Indonesian citizen (WNI). This historical study is important in view of the fact that the phenomenon of the Arabism movement which is now emerging through the involvement of symbols and the identity of the oneness tends to place Arab-Hadrami as opposed to the direction and commitment of the nation.
\end{abstract}

Keywords: Arab-Hadrami; Identity; Nationalism.

\section{Abstrak}

Artikel ini membahas mengenai Sumpah Pemuda Arab pada 1934 yang menjadi cikal bakal pembentukan organisasi Arab-Hadrami nasionalis pertama, Persatuan Arab Indonesia (PAI) yang di kemudian hari berubah menjadi Partai Arab Indonesia (PAI). Artikel ini disusun dengan menggunakan metode sejarah. Sumpah Pemuda Arab 1934 adalah jawaban dari pergulatan identitas dan nasionalisme orang Arab-Hadrami untuk menunaikan haknya sebagai bagian dari warga bangsa Indonesia. Kajian historis mengenai hal ini penting mengingat fenomena gerakan Arabisme yang saat ini mengemuka melalui pelibatan simbol-simbol dan identitas kearaban cenderung menempatkan orang Arab-Hadrami seolah berseberangan dengan arah dan komitmen kebangsaan.

Kata Kunci: Arab-Hadrami; Identitas; Nasionalisme.

\section{PENDAHULUAN}

Di tengah pusaran politik identitas pascaReformasi, pergulatan identitas para keturunan Arab-Hadrami di Indonesia semakin menarik untuk dikaji. Lebih dari satu abad sejak kajian klasik van den Berg mengenai komunitas ArabHadrami pada 1886 dipublikasikan, ia telah mengawali kajian mengenai komunitas ini dan telah "mendorong" para sarjana terus mengaji tentang diaspora dan hibriditas Hadrami di Indonesia pada khususnya serta Asia Tenggara dan Samudra Hindia pada umumnya (Feener, 2004: 353-372). Berg telah menyuguhkan sebuah kajian etnografis yang komprehensif mengenai komunitas yang dulu dianggap oleh pemerintah kolonial Belanda sebagai salah satu ancaman terbesar dominasi mereka (Alatas, 2010:xvii).

Pergulatan identitas orang Arab-Hadrami sebagai akibat dari diaspora, dapat dirujuk pada fenomena diaspora "tua", yang telah berlangsung dalam skala besar sejak pertengahan abad ke-18 hingga akhir 1950-an (Smith, 1997:1-8). Di tengah diskriminasi yang diberlakukan oleh Kolonial Belanda, orang Arab-Hadrami memainkan peranan mereka baik di bidang sosial, politik, maupun ekonomi. Di tempat yang baru, 
para imigran Hadrami ini turut ambil bagian dalam memperluas pasar bisnis, memperoleh kesejahteraan, dan mengirimkannya kembali ke tanah Hadramaut (Alatas, 2015: 6). Kontak antara Jawa dan Hadramaut ini sekaligus menjadi gambaran eksistensi komunitas Hadrami di kawasan Asia Tenggara. Para pelaku diaspora Hadrami, tidak hanya mengirimkan uang kepada keluarga mereka, tetapi juga mengirim anak-anak mereka ke Hadramaut untuk memperoleh pendidikan. Bahkan, ada sebagian dari mereka yang menjalin kontak dengan aktivitas-aktivitas politik di Hadramaut (Jonge dan Kaptein, 2002: 3). Namun, oleh karena gagasan nasionalisme dan diskursus mengenai nation-states, aktivitas ini menurun drastis (Slama, 2005:111-112).

Kisah di atas adalah gambaran bagaimana dinamika diaspora orang Arab-Hadrami berlangsung dan upaya mereka dalam beradaptasi di lingkungan yang baru. Sejarah komunitas Hadrami dan negeri asal mereka, Hadramaut, adalah sejarah tentang bentuk globalisasi yang paling awal yang berdasar pada pelayaran dan perdagangan. Selama berabad-abad, migrasi telah memainkan peran penting dalam kehidupan masyarakat Hadrami (Jacobsen, 2009:2). Jumlah para migran dan intensitas kontak antara tanah air Hadramaut dan komunitas diaspora mereka semakin meningkat, terutama setelah penggunaan kapal uap meramaikan perjalanan laut (Berg, 2010: 95-96; Freitag, 1999: 82).

Kisah orang-orang Hadrami di Indonesia umumnya adalah kisah sukses, terutama dalam bidang perdagangan, politik, pendidikan, dan agama. Sementara para pelaku diaspora Hadrami dipengaruhi oleh masyarakat lokal baik secara sosial maupun budaya. Mereka tidak berlaku pasif terhadap kondisi-kondisi baru yang melingkupi kehidupan mereka. Bahkan, beberapa dari mereka memberikan pengaruh sangat kuat terhadap kehidupan masyarakat lokal, sebagai contoh adalah di bidang pengajaran dan pendidikan Islam. Secara umum, ketika beberapa pelaku diaspora Hadrami masih melestarikan kebiasaan dan identitas Hadrami, beberapa dari mereka justru mendemonstrasikan kreativitas sosial dan budaya sebagai upaya untuk melebur dengan kebudayan dan kehidupan sosial masyarakat. Dinamika migrasi dan diaspora orang Arab-Hadrami di Indonesia memasuki babak baru yang dramatis pada awal abad ke-20. Para tokoh Arab-Hadrami di Jawa mendirikan lembaga pendidikan dan surat kabar yang membentuk identitas kolektif baru yang moderen (Mandal, 2002:163).

Pada awal abad ke-20, hasil dari proses diaspora Hadrami ini adalah juga pendirian institusi-institusi pendidikan moderen, seperti Jam'iyyat Khair dan Jam'iyyah al-Islah wa alIrsyad (Al-Irsyad). Kedua lembaga pendidikan ini menghasilkan dua kelompok besar dalam internal komunitas Arab-Hadrami, yakni tradisionalis (Jam'iyyat Khair) yang diisi oleh golongan Alawiyin (Ar-Rabithah) dan reformis yang diisi oleh golongan Al-Irsyad (Mobini, 1999). Kedua kelompok ini tidak hanya mewakili pertentangan yang sama di tanah asal, yakni Hadramut, tetapi menjadi bahan perdebatan mereka di tanah air yang baru. Kelompok tradisionalis yang diwakili oleh golongan sayid, dan kelompok reformis yang diwakili oleh golongan non-sayid, pada masa berikutnya telah menjelma dari perdebatan sosial menjadi perdebatan doctrinal (Rijal, 2017: 23).

Apa yang menarik pada fase tersebut adalah kemunculan intelektual-intelektual "baru" yang "progresif" yang terlibat aktif dalam diskursus dan menjadi motor penggerak kebangkitan Arab-Hadrami di Indonesia, baik dari golongan non-sayid maupun golongan sayid. Diskursus ini juga telah mengubah perdebatan dari sayid dan non-sayid menjadi totok dan peranakan. Puncak dari pergulatan tersebut adalah Konferensi Keturunan Arab pada Oktober 1934 yang melahirkan Sumpah Pemuda Arab di Semarang. Sebagai hasil kesepakatan internal orang Arab-Hadrami, sumpah pemuda ini adalah sebuah langkah revolusioner. Atas dasar itu, artikel ini bertujuan untuk mengaji pergulatan pemikiran tokoh-tokoh Arab-Hadrami, terutama A.R. Baswedan (Al-Irsyad) dan Hoesin Bafagieh (Ar-Rabithah) dalam menumbuhkan kesadaran berbangsa dan bertanah air melalui otokritik mereka terhadap tradisi dan pola-pola lama yang melingkupi kehidupan orang-orang ArabHadrami. 


\section{METODE}

Kajian ini dilakukan dengan menggunakan metode sejarah yang mencakup empat tahap, yaitu heuristik, kritik sumber, interpretasi fakta, dan historiografi. Sumber-sumber yang digunakan diperoleh dari Arsip Nasional Republik Indonesia (ANRI), Perpustakaan Nasional Republik Indonesia (PNRI), Perpustakaan Departemen Sejarah Fakultas Ilmu Budaya Universitas Diponegoro, dan koleksi pribadi.

Sumber primer yang dikumpulkan dalam artikel ini adalah berupa tulisan-tulisan mengenai Sumpah Pemuda Arab 1934 dan Persatuan Arab Indonesia (PAI) yang tersebar dalam surat kabar, seperti Matahari, Aliran Baroe, Zaman Baroe, Insaf, dan Nusa Putra. Selain itu, sumber sekunder yang digunakan adalah berupa artikel dalam buku, media massa cetak, dan online.

\section{HASIL DAN PEMBAHASAN}

\section{Dari Persoalan "Bahaya Arab" Hingga Sayid vs Non-Sayid}

"Bahaya Arab" adalah istilah yang disematkan oleh pemerintah Kolonial Belanda untuk mengidentifikasi persoalan orang-orang keturunan Arab. Identifikasi tersebut muncul dari kecurigaan pemerintah, bahwa orang-orang Arab adalah motor dari gerakan-gerakan pemberontakan melawan pemerintah kolonial (Berg, 1996: 21). Meskipun Berg menyatakan bahwa orangorang Arab yang telah berasimilasi dengan pribumi sejak berabad-abad adalah juga pribumi, hal itu tidak mengurangi kecurigaan pemerintah Kolonial terhadap eksistensi orang-orang Arab. Merujuk pada Indische Staats-regeling (IS), orang-orang Arab bersama dengan orang Cina dan India, dimasukkan dalam kategori Vreemde Oosterlingen (golongan Timur Jauh), yang terpisah dari mayoritas pribumi muslim (Algadri, 1996: 59).

Meskipun dalam politik kolonial, orang Arab-Hadrami berada pada level dua, di antara orang Eropa pada level pertama dan pribumi pada level ketiga, mereka tetap tidak memiliki arti politis yang penting bagi pemerintah kolonial.
Selain itu, orang Arab-Hadrami juga menjadi kelompok yang diawasi oleh pemerintah Kolonial Belanda, karena dianggap ikut menggelorakan Pan-Islamisme. Sementara itu, di kalangan pribumi, orang Arab-Hadrami belum dapat diterima sepenuhnya. Hal itu karena, meskipun sama-sama memeluk agama Islam, mereka dianggap memiliki status hukum yang berbeda di mata kolonial (Noer, 1980).

Selain antara orang Arab-Hadrami dengan pemerintah kolonial, persoalan juga muncul dalam dinamika internal orang Arab-Hadrami. Dinamika yang dimaksud adalah persoalan sayid dan non-sayid. Golongan non-sayid menganggap golongan sayid, menikmati status sosial dan religius mereka yang mereka dapatkan baik dari saudara-saudara Hadrami mereka maupun dari masyarakat pribumi. Pertentangan ini menjadi latar belakang kelahiran apa yang disebut dengan Nahdlah Hadrami (kebangkitan Hadrami). Nahdlah Hadrami bertujuan untuk menumbuhkan kesadaran orang-orang Arab untuk mengakui persamaan sosial dan pikiranpikiran maju dengan mengadopsi ide dan institusi-institusi moderen (Kesheh, 2007).

Terdapat tiga institusi moderen yang menggambarkan kebangkitan Hadrami, yakni organisasi sosial, sekolah, dan surat kabar (Kesheh, 2007: 233). Sekolah moderen pertama adalah Jam'iyyat Khair yang didirikan di Batavia pada 1901. Meskipun sekolah ini didirikan oleh kelompok sayid, beberapa pengurus sekolah ini berlatar belakang non-sayid. Sekolah ini telah memasukkan kurikulum Barat dengan sekaligus mempertahankan pelajaran keagamaan yang tradisionalis. Sekolah ini juga mengundang guruguru dari Timur Tengah untuk mengajar, salah satunya adalah Syaikh Ahmad As-Surkati (Kesheh, 2007: 233).

Surkati adalah seorang yang berasal dari Sudan dan mendapatkan pendidikan di Mekah. Selama di Mekah, ia mempelajari dan menerapkan gagasan reformisme Islam dari Mesir dan menjadi aktivis dalam pergerakan modernisme Islam pada masa-masa berikutnya (Jonge, 1993: 81). Tidak heran pandangan reformismenya dengan segera menjadi telah memicu konflik dengan komunitas Hadrami. Pada 1912, ketika ia mengunjungi temannya, Awad Sungkar Al-Urmei 
di Solo, Surkati ditanya mengenai status perkawinan (kafaah) antara perempuan sayid (syarifah) dengan laki-laki non-sayid. Di sana, ia menyatakan bahwa perkawinan tersebut sah (Kesheh, 2007: 233). Pada kesempatan lain, ia juga mengritik praktik cium tangan (taqbil). Pandangannya ini telah membangkitkan ketidaksukaan para tokoh senior Jam'iyyat Khair konservatif dan mendesak Surkati untuk mengundurkan diri (Kesheh, 2007: 233).

Pengunduran diri Surkati dari Jam'iyyat Khair, telah pula menyebabkan konflik internal tersebut semakin mendalam. Pada umumnya, para pendukung Surkati adalah golongan orang Arab-Hadrami non-sayid. Melalui bantuan seorang Kapiten Arab, Syaikh Umar Yusuf Manggus, Surkati mendirikan Madrasah AlIrsyad Al-Islamiyah di Batavia. Untuk mendukung lembaga pendidikan barunya ini, Surkati mendirikan organisasi Jam’iyyah Al-Irsyad AlIslamiyah Al-Arabiyah (selanjutnya disebut AlIrsyad) pada 1914. Seperti halnya Surkati, tujuan Al-Irsyad adalah menggelorakan gerakan reformisme Islam (Jonge, 2004:378).

Untuk merespon perkembangan Al-Irsyad yang demikian cepat, sejumlah sayyidmendirikan sebuah organisasi komunitas yang baru yang mereka sebut Rabithah Alawiyah, atau persatuan para keturunan Nabi. Organisasi ini memiliki kantor harian yang disebut Al-Maktab Ad-Daimi yang melakukan pelayanan pencatatan tentang sejarah dan geneologi para sayid (AD/ART Rabithah Alawiyah).

Kemunculan dua organisasi ini telah memunculkan dua kelompok besar di internal Arab-Hadrami, yakni kelompok Irsyadis di satu sisi, dan Alawiyah (Alawiyin) di sisi lain. Panggung perdebatan mereka dipublikasikan melalui surat-surat kabar. Menurut Kesheh, terdapat tiga tema utama perdebatan, yakni kewajiban mencium tangan sayid (taqbil), batasan perkawinan antara perempuan sayid dengan laki-laki non-sayid, dan penggunaan gelar sayid (Kesheh, 1999: 92).

Selain perdebatan sayid dan non-sayid, alam pikiran awal abad ke-20 yang diwarnai pula oleh iklim pergerakan, telah memuncul-kan sebagian kecil dari komunitas Arab-Hadrami yang telah menerima gagasan-gagasan pembaharuan. Perdebatan yang dimaksud dalam konteks ini adalah gagasan mengenai tanah leluhur dan tanah kelahiran, yakni apakah orang Arab-Hadrami harus loyal kepada tanah leluhurnya di Hadramaut, atau tanah kelahiran mereka yang baru, Indonesia. Kelompok yang pertama disebut dengan kaum tua, sedangkan kelompok yang kedua disebut dengan kaum muda. Kaum tua menganggap bahwa orientasi tanah air orang-orang Hadrami haruslah pada tanah leluhur mereka di Hadramaut, sedangkan kaum muda menentang anggapan tersebut dan berkeyakinan bahwa tanah air mereka adalah tanah kelahiran mereka yang baru, yakni Indonesia. Hal ini seperti digambarkan dalam Pewarta Arab sebagai berikut.

\begin{abstract}
"Kaoem Indo Arab yang berada di Indonesia ini, dengan tanah leloehoer kita Hadramaut masih banyak djoega, oempamanja: perhoeboengan-perhoe boengan Familier, warisan dan lain-lainnja, tetapi kendatipoen bagaimana perhoeboengan-perhoeboengan itoe ti dak sebanjak dan serapat perhoe boengan-perhoeboengan bapak-bapak kita kaoem walaiti (totok). Dalam hal itoe sangatlah besar bedanja kita dengan mereka itoe ... sedang oentoek kita tjoema ada satoe tanah leloehoer belaka, karena jang sesoenggoehnja tanah air kita dan toempah darah kita, adalah si tjantik Indonesia ini ... orang tak dapat menjalahkan kita jang tidak memperbintjangkan apa-apa tentang Hadramaut" (Pewarta Arab, 11 Desember 1933:13).
\end{abstract}

Selain soal orientasi tanah leluhur dengan tanah kelahiran yang baru, kaum muda juga mendorong kepada kaum tua untuk menyudahi perselisihan tentang siapa di antara mereka yang memiliki status lebih tinggi, apakah sayid atau non-sayid. Bagi kaum muda, daripada mengurus hal-hal yang sepele, seperti soal perselisihan pengangkatan penghulu, kafaah (perkawinan perempuan sayid), taqbil (mencium tangan), dan masalah-masalah yang lain, adalah lebih penting untuk membahas mengenai persoalan sosial ekonomi di antara mereka. Puncak dari gerakan kaum muda ini adalah Konferensi Peranakan 
Arab yang diselenggarakan di Semarang pada Oktober 1934.

\section{Sumpah Pemuda Arab, 1934: Antara "Citra Arab" dan Tanah Air Baru}

\section{Percik Pemikiran Tokoh-Tokoh Arab-Hadrami yang Nasionalis}

"Arab Indonesia dibesarkan dengan gado-gado, bukan dengan mulukhia. Dengan durian, bukan dengan kurma. Dengan sejuknya hawa gunung, bukan dengan panasnya padang pasir! Mereka dihidupkan bukan di pinggir Dajlah dan Furat, tetapi di pinggir Musi, Kapuas, Bengawan, dan Brantas. Lebih gurih minyak kelapa daripada minyak samin. Sebab itu jalan selamat bagimu, di hari depanmu ialah leburkan diri ke dalam bangsa ibumu. Tanah airmu ialah Indonesia! (Baswedan, 1934).

Pernyataan di atas adalah cuplikan tulisan A.R. Baswedan berjudul "Peranakan Arab dan Totoknya," yang diterbitkan oleh Surat Kabar Matahari di Semarang pada 1 Agustus 1934. Tulisan tersebut dibuat oleh A.R. Baswedan, seorang peranakan Arab-Hadrami, menjelang Konferensi Peranakan Arab di Semarang pada 45 Oktober 1934. Tulisan tersebut semakin membuat heboh, saat satu bulan berikutnya, A.R. Baswedan menyertakan foto dirinya mengenakan blangkon dan pakaian khas Jawa pada surat kabar yang sama. Pada foto itu, tampak A.R. Baswedan duduk santai bersama Soeljoadikoesoemo dan istrinya, pasangan priyayi berbusana Jawa, dengan tulisan yang juga membuat heboh,

"Apakah foto ini tida meroepakan peranakan Arab dari generatie jang aken dateng?!!!” (Matahari, 1 September 1934; Suratmin dan Kwartanada, 2014).

Tulisan dan foto tersebut, kontan membuah heboh karena pada masa menjelang medio awal abad ke-20, adalah aneh melihat seorang peranakan Arab mengenakan pakaian ala Jawa. Hal itu telah membuat A.R. Baswedan mendapatkan cercaan dari kelompok Arab-
Hadrami yang lain, karena dianggap telah menghina nenek moyang mereka di Hadramaut. Hasil dari konferensi tersebut adalah Sumpah Pemuda Arab dan organisasi Arab-Hadrami nasionalis, Persatuan Arab Indonesia (PAI).

A.R. Baswedan atau Abdul Rahman Baswedan dilahirkan di Kampung Ampel pada 9 September 1908. Kakeknya, Umar bin Abubakar bin Mohammad bin Abdullah berasal dari Hadramaut (Yaman Selatan). Sejak kedatangannya di Nusantara, kakek Baswedan telah menikah dengan wanita pribumi (Suratmin dan Kwartanada, 2014: xvi). Dari nama yang disandangnya, tampak bahwa Baswedan bukan berasal dari golongan sayid. Hal ini membuat keluarga Baswedan tidak berada pada level teratas dalam golongan internal komunitas Hadrami. Sejak kedatangannya di Hindia Belanda, orang Arab-Hadrami meneruskan hirarkhi yang kaku atas dasar keturunan. Kelompok sayid adalah kelompok yang tertinggi dan mengklaim sebagai keturunan Nabi Muhammad SAW dari jalur Husain. Mereka juga disebut Alawi, cucu dari Ahmad bin Isa. Dari nama inilah, golongan ini juga disebut dengan nama Alawiyah. Berturutturut setelah golongan sayid, adalah syaikh, qabili (gabili), dan masakin. Namun, golongan sayid tetaplah dianggap istimewa (Jonge, 2004: 376377).

Keluarga Baswedan adalah golongan Syaikh/Masyaikh, golongan kedua dari hirarkhi komunitas Arab-Hadrami dan masuk dalam kategori kelas pedagang. Sebagai generasi ketiga sejak kedatangan kakeknya, Baswedan dan banyak orang Arab-Hadrami lain yang dilahirkan dari pasangan Hadrami-pribumi adalah kategori muwallad (peranakan). Sementara mereka yang dilahirkan di Hadramaut, atau lahir dari keturunan orang tua Hadramaut masuk dalam kategori wulaiti (totok) (Suratmin dan Kwartanada, 2004: 10). Keduanya, muwallad dan wulaiti menjadi bentuk diskriminasi lain dalam komunitas Arab-Hadrami.

Pendidikan utama yang diperoleh Baswedan berasal dari keluarga, yang sebetulnya masih melestarikan nilai-nilai tradisional. Namun, jiwa pemberontak dalam diri Baswedan sepertinya adalah karakter pribadinya yang kuat dan kritis. Bakatnya ini semakin kuat dan melekat 
pada diri Baswedan saat ia memasuki dunia pendidikan. Ia mendapatkan pendidikan dari di Madrasah Al-Irsyad, di bawah pimpinan Syaikh Ahmad As-Surkati. Kemudian, ia juga melanjutkan pendidikannya di sebuah sekolah Arab moderen yang bernama Hadramaut School di Surabaya (Suratmin dan Kwartanada, 2004: 33-34). Baswedan menikah dengan Syeikhun dan memiliki sembilan anak. Setelah istri pertama meninggal pada 1948, ia menikah lagi dengan Barkah Al-Ghanis pada 1950 dan memiliki dua anak (Suratmin dan Kwartanada: 54-56).

Baswedan banyak bekerja di dunia jurnalistik dan politik. Ia sempat bergabung di harian Soeara Oemoem di Surabaya yang diasuh oleh dr. Soetomo. Meski tidak lama ia bekerja di harian ini, harian ini telah memulai babak baru dalam sejarah hidup Baswedan sebagai jurnalis. Setelah memutuskan keluar, Baswedan pindah ke Semarang pada akhir 1934. Di sini, Baswedan melanjutkan bakat jurnalistiknya dengan bekerja di harian Matahari (http://www.majalah. tempointeraktif.com/id/arsip/2008/12/15/IM $\mathrm{Z} / \mathrm{mbm} .200$, diakses pada 8 Agustus 2018). Tulisan-tulisannya di harian Matahari, telah mengantarkan Baswedan pada dunia pergerakan dan politik. Sikapnya yang kritis terhadap tradisi Arab-Hadrami menjadikannya tokoh penting rekonsiliasi totok dan peranakan.

Selain Baswedan, tokoh lain yang dikenal kritis adalah Hoesin Bafagieh. Berbeda dari Baswedan yang berasal dari golongan non-sayid, Hoesin Bafagieh adalah jurnalis dan tokoh pergerakan orang Arab-Hadrami yang berasal dari golongan sayid. Tidak diketahui secara pasti kapan tanggal, bulan, dan tahun kelahiran Hoesin Bafagieh. Namun, diyakini ia dilahirkan di Surabaya pada 1900, beberapa tahun sebelum Baswedan dilahirkan (Hayaze', 2017: 9). Bafagieh menikah empat kali selama hidupnya, tetapi ia tidak pernah memiliki dua istri dalam waktu bersamaan. Dari empat pernikahan tersebut, Bafagieh mendapatkan 11 anak. Ia meninggal pada 1958 di Surabaya (Hayaze', 2017:9).

Seperti halnya Baswedan, Bafagieh juga dikenal sebagai jurnalis yang kritis. Ia dikenal sebagai pendiri majalah Harian Baroe pada 1939 dan bersama-sama dengan Salim A. Miskati, Bafagieh mendirikan majalah Zaman Baroe hampir satu dekade sebelumnya (Hayaze', 2017:9). Baswedan sempat menawarkan diri untuk ikut menulis dalam penerbitan tersebut. Namun, Bafagieh menolaknya.

Meski demikian, Bafagieh dan Baswedan adalah tokoh nasionalis yang berdarah ArabHadrami. Melalui Persatuan Arab Indonesia yang kemudian berubah menjadi Partai Arab Indonesia, mereka aktif menumbuhkan kesadaran berbangsa dan bertanah air Indonesia di tengah orang-orang Arab-Hadrami (https://majalah.tempo.co/read/155585/meng enang-hoesin-bafagih-dan-tonil-fatimah, diakses pada 8 Agustus 2018). Persahabatan Bafagieh dan Baswedan sudah dimulai sejak 1924. Mengenai awal pertemuannya dan persahabatannya dengan Baswedan, Bafagieh menuturkan.

"Saya mulaikan penuturan saya semenjak pada tahun 1924 yang lalu! Pada masa itu, masing-masing dari kaum muda AlIrsyad dan Ar-Rabi-thah terbit semangat opposite terhadap kaum tuanya yang senantiasa menjadi halangan buat mereka mencapai cita-cita kemajuan lebih jauh, mengikuti perubahan zaman. Maka beberapa pemuda Al-Irsyad dengan beberapa pemuda Ar-Rabithah itu telah dapat mengadakan semacam "persatuan" yang bisa melahirkan satu perkum-pulan bersama "Bibliotheeq At-Tahdi biyah" di Surabaya sekedar buat tempat mereka bergaul dan mendekat-kan hubungan, tetapi dengan tanpa satu dasar yang tegas dan tentu. Hanya berdasar atas perasaan ingin bersatu dan jengkel terhadap kaum tuanya masing-masing. Saudara AR. Baswedan termasuk golongan itu dari pihak Al-Irsyad, seperti juga saya dari pihak Ar-Rabithah (Hayaze', 2017:910)."

Saat itu, lembaga yang disebut Ar-Rabithah belum berdiri. Apa yang dimaksud Ar-Rabithah oleh Bafagieh adalah kelompok Alawiyin. Sebagai seorang Arab-Hadrami berlatar belakang sayid, Bafagieh adalah salah satu tokoh jurnalis dari kalangan Alawiyin yang cukup penting. Bersamasama dengan Baswedan, ia mendirikan Jam'iyyah 
At-Tahdibiyah, organisasi muwallad pertama yang didirikan pada 1 Agustus 1924 di Surabaya. Salah satu tujuan dari organisasai ini adalah menyatukan golongan muwallad dari dua kelompok utama, yakni Al-Irsyad atau golongan Syaikh/ Masyayikh dengan golongan ArRabithah atau Alawiyin. Majalah Zaman Baroe menyebutkan tujuan organisasi At-Tahdibiyah adalah "mengangkat derajat sosial orang Arab Hindia dengan mengesampingkan seluruh perasaan dan kepartaian (Hayaze': 2017:10-11).

Sebetulnya, selain organisasi AtTahdibiyah, orang Arab-Hadrami telah memiliki organisasi baru yang dinamakan Indo Arabische Verbond (IAV) pada 1930. Organisasi ini meniru gerakan Belanda Indo yang menamakan diri Indo Europeesch Verbond (IEV). Pendiri organisasi ini adalah Al-Amudi, seorang keturunan Arab asal Ambon dan tinggal di Surabaya. IAV gagal untuk menjadi wadah semua kelompok dalam internal komunitas Arab-Hadrami karena ketergantungannya pada dukungan orang-orang kaya dan karakter organisasinya yang tidak dapat melepaskan diri dari sistem sosial yang berlaku di Hadramaut. Sentimen ras yang menyatakan bahwa orang keturunan Arab adalah orang Arab, telah menyebabkan perasaan tidak puas dari para anggota. Baswedan adalah salah satu anggota IAV yang akhirnya memutuskan keluar dari organisasi ini (Hayaze', 2017: 10-11).

\section{Dari Konferensi Keturunan Arab 1934 di Semarang hingga Sumpah Pemuda Arab 1934}

Tampaknya, usaha kaum muda untuk merebut simpati dari kalangan Arab-Hadrami mulai memperoleh hasil. Usaha tersebut terutama digelorakan oleh kelompok non-sayid yang dipimpin oleh Baswedan. Usaha ini, selain sebagai upaya untuk melancarkan kampanye persatuan dan nasionalisme orang ArabHadrami, sekaligus menjadi kritik terhadap status sosial golongan sayid. Mereka menganggap bahwa kelompok sayid adalah kelompok yang paling bertanggung jawab terhadap kemunduran kehidupan sosial budaya orang Arab-Hadrami. Status kelompok sayid yang dianggap istimewa, bagi Baswedan adalah wujud dari pengakuan bahwa Hadramaut adalah satu-satunya tanah air.
Bahkan, mengenai gelar sayid (tuan) ini, Baswedan mengusulkan untuk diganti menjadi al-akh (saudara). Gelar sayid ini selain menjadi penghambat kompromi antara dua kelompok yang bertikai, sekaligus menjadi masalah yang menyebabkan pertikaian berlarut-larut (Algadri, 1996:166-167). Kelompok kaum tua yang kontra-kaum muda bukan tidak tinggal diam. Oleh karena mereka tidak memiliki media untuk merespon gagasan kemajuan kaum muda ArabHadrami, mereka menggunakan saluran media surat kabar yang dimiliki oleh Indo Arabische Verbond (IAB) yang dipimpin oleh Al-Amudi (Algadri, 19996:166).

Namun demikian, tidak berarti bahwa kelompok sayid sama sekali tidak ada yang berpihak pada gagasan Baswedan. Nuh Al-Kaff dan Abu Bakar Al-Atas misalnya, adalah sebagian kelompok sayid yang turut menggelorakan nasionalisme Indonesia bagi orang ArabHadrami dan sekaligus berperan penting dalam pembentukan Persatuan Arab Indonesia (PAI) selain Hoesin Bafagieh. Usaha kelompok muda dari golongan sayid ini dilakukan secara diamdiam untuk menghindari cercaan dari kelompok sayid lain yang memiliki orientasi kebangsaan yang berbeda (Suratmin dan Kwartanada, 2004: 83-84).

Puncak dari gagasan kaum muda ArabHadrami ini adalah berlangsungnya Konferensi Peranakan Arab Indonesia pada 3-5 Oktober 1934 di Semarang. Pada hari pertama konferensi, tibalah di Semarang tokoh-tokoh Arab-Hadrami baik dari unsur Al-Irsyad maupun Ar-Rabithah. Mereka adalah orang-orang yang aktif mengambil bagian penting dalam pertentangan di antara dua perkumpulan tersebut. Mereka yang berjumlah sekitar 40 orang itu, datang dari Surabaya, Semarang, Pekalongan, Solo, dan Jakarta (Suratmin dan Kwartanada, 2014: 80).

Konferensi ini dimotori oleh dua orang jurnalis beretnis Arab terkemuka Nuh Al-Kaff dari Pewarta Arab sebagai Ketua Komite dan A.R. Baswedan dari Matahari sebagai Ketua Konferensi. Selain keduanya, terdapat pula sederet nama jurnalis beretnis Arab yang turut terlibat aktif dalam konferensi, dua di antaranya adalah Hoesin Bafagieh dan A. Miskati dari Zaman Baroe. Jurnalis memang menjadi motor 
utama konferensi yang menghasilkan Sumpah Pemuda Arab itu. Selain karena jurnalistik menjadi satu-satunya pekerjaan yang dapat diperoleh di luar sebagai pegawai pemerintahan, jurnalis memiliki posisi yang istimewa karena menguasai arus informasi. Bagi mereka, menjadi jurnalis selain untuk mencari pengetahuan dan pengalaman adalah mencari kepuasan batin. Melalui tulisan, mereka meyakini dapat melakukan perubahan-perubahan dalam internal kelom-poknya. Melalui sosok Nuh Al-Kaff yang sayid dan A.R. Baswedan yang non-sayid inilah, mengapa Semarang kemudian menjadi tempat penyelenggaraan konferensi.

Baswedan dipilih menjadi ketua dengan banyak pertimbangan. Ia dianggap memiliki latar belakang jurnalis yang kuat dan pergaulan yang luas. Tercatat, ia pernah bergabung dengan AlIrsyad, Muhammadiyah di bawah K.H. Mas Mansur, dan menjadi anggota Biblioteeq AtTahdibiyah (Jam'iyyah At-Tahdibiyyah) persatuan antarpemuda Al-Rabithah dan Al-Irsyad meski tidak berbentuk sebagai organisasi formal. Baswedan juga aktif di Yong Islaminten Bond, redaksi surat kabar Sit It Po pada 1933, redaksi surat kabar Soeara Oemoem pada 1933, dan redaksi surat kabar Matahari 1934 di Semarang. Ia juga dikenal sebagai penganjur pendirian Persatuan Arab Indonesia (Bafagieh, 1939:1-5; Baswedan, 1934:5).

Meski demikian, persolan tanah air dan tujuan utama konferensi menjadi bahan perdebatan penting. Untuk menjawab hal itu, Baswedan mengajukan pokok-pokok pikirannya sebagai berikut.

1. Tanah air peranakan Arab adalah Indonesia.

2. Kultur peranakan Arab adalah kultur Indonesia.

3. Berdasarkan yang di atas peranakan akan wajib bekerja untuk tanah air dan masyarakat Indonesia.

4. Untuk memenuhi kewajiban perlu didirikan organisasi politik khusus untuk peranakan Arab.

5. Menghindarkan dari hal-hal yang menjadi sebab perselisihan dalam masyarakat Arab.
6. Menjauhkan diri dari kehidupan yang menyendiri dan menyesuaikannya dengan keadaan zaman dan masyarakat Indonesia (Majalah Nusa Putra, Mei 1950:5).

Kemudian, hal yang paling menggemparkan dalam konferensi itu, adalah Sumpah Pemuda Keturunan Arab yang berisi tiga butir pernyataan, yaitu:

1. Tanah Air Peranakan (Keturunan) Arab adalah Indonesia.

2. Peranakan Arab harus mening-galkan kehidupan menyendiri (mengisolasi diri).

3. Peranakan Arab harus memenuhi kewajibannya terhadap tanah air dan bangsa Indonesia (Hayaze', 2017: 3).

Konferensi ini sebetulnya membahas tentang pemilihan pemimpin Arab yang akan duduk dalam Volksraad. Hal ini karena, calon yang diajukan oleh Indo Arabische Verbond sudah diajukan oleh kelompok lain (Suratmin dan Kwartanada, 2014: 84-85). Konferensi Peranakan Arab-Indonesia juga berhasil memilih calon-calon yang mewakili mereka dalam Volksraad, yaitu Mohammad bin Aboebakar Alatas, A.R. Alaydroes, Abdullah bin Salim Alatas, dan Ahmad Bachmid. Selain itu, konferensi juga telah berhasil menghasilkan Persatuan Arab Indonesia pada persidangan ketiga dari empat kali persidangan. Konferensi yang berlangsung di rumah Said Behiloel di Kampung Melayu Semarang tersebut telah pula menghasilkan kepengurusan Persatuan Arab Indonesia (PAI) sebagai berikut: A.R. Baswedan (Al-Irsyad) sebagai Ketua; Nuh Al-Kaff (Ar-Rabithah) sebagai Penulis I; Salim A. Maskati (Al-Irsyad) sebagai Penulis II; Segaf As-Segaf (Ar-Rabithah) sebagai Bendahara; dan Abdulrahim Argubi (AlIrsyad) sebagai Komisaris. Sebagai komisaris, Argubi dibantu oleh Ahmad Bahaswan (Solo), H.A. Djaelani (Pekalongan), Mohmad bin Aboebakar Alatas dan A.R. Alaydroes (Jakarta) (Pewarta Arab No. 5, 1934:1). Pada konferensi itu, telah pula diputuskan mengenai azas, tujuan, dan haluan Persatuan Arab Indonesia. 
Aliran Baroe yang dipimpin oleh Hoesin Bafagieh berhasil menjadi penyebar informasi dan perkembangan serta ide-ide kemajuan dari PAI. Aliran Baroe dan Hoesin Bafagieh juga dianggap berhasil sebagai salah satu corong yang "membangkitkan" kesadaran berbangsa dan bertanah air Indonesia di kalangan orang Arab Indonesia (Hayaze', 2017:17). Perihal PAI, Bafagieh menulis.

"Sekarang menjadi terang, bahwa tidak dapat disangkal lagi, yang itu persatuan telah tercipta berkat adanya PAI. Hal ini saja sudah terpaksa nyatakan sekarang, sebab antara mereka yang tidak sabar banyak bertanya-tanya: "Hasil apakah yang sudah ditimbulkan oleh PAI dari semenjak berdirinya" (Hayaze', 2017:46-47).

Mengenai peran penting Bafagieh dan Aliran Baroe, Baswedan menyatakan:

“Maka jika kita menjebut Aliran Baroe
telah berjasa artinya ialah bahwa saudara
Bafagieh yang berjasa” (Hayaze', 2017:8).

Sumpah Pemuda Arab 1934 dan kelahiran PAI yang revolusioner itu tentu mengundang reaksi baik dari kalangan keturunan Arab maupun di luar kalangan Arab, seperti Jawa, Cina, dan Belanda. Kalangan Arab-Hadrami yang menyetujui gagasan tersebut, rata-rata adalah mereka yang memiliki latar belakang non-sayid dan sayid "progresif". Golongan sayid yang setuju karena melalui Sumpah Pemuda Arab yang kemudian dikukuhkan menjadi PAI akan menyebabkan sekat-sekat stratifikasi sosial yang didasarkan pada geneologi "suci" Nabi menjadi longgar dan tidak ada lagi. Hal ini secara psikologis dapat dipahami, karena akan meningkatkan harkat dan martabat mereka dan akan menempatkan mereka pada posisi yang setara dengan mereka yang mendaku sebagai keturunan Nabi itu. Keluarga Arab-Hadrami utama yang menjadi penyokong terbesar PAI adalah Miskati, Baswedan, Sungkar, Basajut, dan Bahaswan. Sementara, mereka dari kalangan sayid yang menyokong hasil Sumpah Pemuda Arab dan PAI dilatarbelakangi oleh pendidikan, wawasan, dan pergaulan. Mereka yang memililiki latar belakang pendidikan tinggi pada waktu itu, rata-rata memiliki pemikiran yang terbuka dan pergaulan yang luas.

Mereka yang menentang pendirian PAI pada masa-masa selanjutnya, mendirikan Indo Arabische Beweging (IAB) pada 1939. Menurut Pluvier, seperti dikutip oleh Al-Gadri, tujuan utama pendirian $\mathrm{IAB}$ adalah seratus persen berbeda dengan PAI. Bahkan, melalui Al-Amudi, ketua IAB, menyatakan bahwa nasionalisme adalah berbahaya dan tidak sehat. Pendirian IAB, terutama adalah saat PAI berubah menjadi organisasi politik sesuai hasil Konggres PAI pada 1937 (Algadri, 1996:168).

Kalangan pribumi yang mendukung gagasan Sumpah Pemuda Arab dan PAI berasal dari kalangan pergerakan terutama yang berasaskan Islam. Mereka menganggap bahwa pendirian PAI akan menambah massa dalam Islam. Bagaimanapun, Arab akan selalu identik dengan Islam. Atas anjuran Pemandangan, surat kabar dari kelompok pergerakan pribumi, nama surat kabar Pewarta Arab harus diganti untuk menghilangkan kesan kesukuan. Mereka mengusulkan untuk mengubahnya menjadi Penyedar. Pewarta Arab pun mengakhiri penerbitan pada Rabu, 17 Oktober 1934 (Pewarta Arab, 17 Oktober 1934). Kalangan etnis Cina yang mendukung juga diperoleh dari kalangan pergerakan, terutama dari kelompok Liem Koen Hian dan Tjoa Tjoe Liang. Mereka adalah motor utama Partai Tionghoa Indonesia (PTI) yang telah berdiri pada 1932. Sementara, kalangan Belanda yang mendokong masih bersikat abu-abu. Hal itu terutama karena mereka sementara masih melihat bahwa pergerakan Arab masih belum menampakkan gejala radikal dan ekstrim terhadap pemerintah Belanda. Mereka yang mendukung penuh adalah Teuuween dari Partai Insulinde, sosok yang dikenal nasionalis (Panji Islam No. 34, 19 Agustus 1940:639).

Sumpah Pemuda Arab 1934 menjadi langkah yang revolusioner, tidak hanya bagi keturunan Arab, tetapi juga bagi seluruh bangsa Indonesia. Bahkan, Ki Hajar Dewantara menyebut arti sumpah tersebut dalam sambutan memperingati Hari Kesadaran Bangsa Indonesia Keturunan Arab yang ke-20 di Surakarta sebagai berikut. 
"saudara-saudara kita jang berke-turunan Arab tadi tidak merasa mempunyai dan tidak mengakui adanja bangsa dan negara di luar Indonesia yang mengikat mereka, baik lahir maupun bathin.

...

keikhlasan saudara-saudara keturunan Arab tadi tidak sadja mengun tungkan diri mereka sendiri, namun menguntungkan negara kita pula, sebagai negara yang "modern" dan berdasarkan "Pantjasila (Algadri, 1996: 211).”

\section{SIMPULAN}

Sumpah Pemuda Arab 1934 telah menjadi puncak pergulatan identitas orang Arab-Hadrami dari diskriminasi baik yang mereka dapat dari pemerintah Kolonial Hindia Belanda maupun di internal orang-orang Arab-Hadrami. Diskrimasi internal yang dimaksud adalah pergeseran perdebatan dari sayid dan non-sayid menjadi totok dan peranakan.

Sumpah Pemuda Arab 1934 meneguhkan bahwa Indonesia adalah tanah air orang ArabHadrami. Keturunan Arab adalah putra bangsa Indonesia dan harus mengabdi kepada tanah air. Gerakan yang cepat menyebar tidak hanya di Jawa, tetapi juga di Sumatra, Sulawesi, dan Kalimantan ini menjadi bukti, bahwa orang ArabHadrami memiliki komitmen bahwa Indonesia adalah benar-benar tanah airnya.

\section{REFERENSI}

Baswedan, A. R. (1934). Catatan Tentang: Soempah Pemoeda Indonesia Ketoeroenan Arab. Nasional Press: Surabaya.

Baswedan, A. R. "Peranakan Arab dan Totoknya," Matahari, Tahun 1 No. 1, Semarang, 1 Agustus 1934.

AD/ART Rabithah Alawiyah.

Alatas, Ismail Fajrie (2015). "Gold and Silver, Branded Horses, and Well-Tilled Land: Gender and Hadrami Migration", Indonesia Feminist Journal 3 (1): 4-13.

Alatas, Ismail Fajrie (2010). "Menjadi Arab: Komunitas Hadrami, Ilmu Pengetahuan Kolonial \& Etnisitas", dalam L.W.C. van den Berg, Orang Arab di Nusantara, terjemahan Rahayu Hidayat. Jakarta: Komunitas Bambu.

Algadri, M. Hamid (1996). Islam dan Keturunan Arab: dalam Pemberontakan Melawan Belanda. Jakarta: Mizan.

Berg, L.W.C. van den (2010). Orang Arab di Nusantara, terjemahan Rahayu Hidayat. Jakarta: Komunitas Bambu.

Feener, R. Michael (2004). "Hybridity and the "Hadhrami Diaspora" in the Indian Ocean Muslim Networks", Asian Journal of Social Science (32) 3: 353-372.

Freitag, Ulrike (1999). "Hadramaut: a Religious Center for the Indian Ocean in the Late $19^{\text {th }}$ and Early $20^{\text {th }}$ Centuries", Studia Islamica 89: 165-183.

Hayaze', Nabil A. Karim (2017). Kumpulan Tulisan \& Pemikiran Hoesin Bafagieh: Tokoh PAI dan Nasionalis Keturunan Arab. Jakarta: Menara Center.

Bafagieh, Hoesin (1939). "Didalam dan Diloear Pergerakan”, Aliran Baroe, Surabaya, No. 6 (Januari 1939) Tahun ke-2, hlm. 1-5.

Jacobsen, Frode F. (2009). Hadrami Arabs in Present-Day Indonesia: An IndonesiaOriented Group with an Arab Signature. London and New York: Routledge.

Jonge, Huub de (1993). "Discard and Solidarity Among the Arabs in the Netherlands East Indies, 1900-1942”, Indonesia, 55 (April): 73-90.

Jonge, Huub de dan Nico Kaptein (2002). "The Arab Presence in Southeast Asia: Some Introductory Remarks", dalam Jonge, Huub de dan Nico Kaptein (Eds). Transcending Borders: Arabs, Politics, Trade, and Islam in Southeast Asia. Leiden: KITLV Press.

Jonge, Huub de (2004). "Abdul Rahman Baswedan and the Emancipation of Hadhramis in Indonesia", Asian Journal of Social Science 32 (3): 373-400.

Kesheh, Natalie Mobini (1997). "Islamic Modernism in Colonial Java: The AlIrshad Movements", Ulrike Freitag dan William G. Clerence Smith (eds.), Hadrami Traders, Scholars, and Statesman 
in the Indian Ocean, 1750s-1960s. Leiden: Brill.

Kesheh, Natalie Mobini (1999). The Hadrami Awakening: Community and Identity in the Netherlands East Indies, 1900-1942. New York: Cornell Southeast Asia Program.

Mandal, Sumit Kumar (2002). "Forging A Modern Arab Identity in Java in the Early Twentieth Century", dalam Huub de Jonge dan Nico Kaptein, Transcending Borders: Arabs, Politics, Trade, and Islam in Southeast Asia. Leiden: KITLV Press, 2002.

Noer, Deliar (1980). Gerakan Modern Islam di Indonesia 1900-1942. Jakarta: LP3ES.

Rijal, Syamsul (2017). "Internal Dynamics within Hadhrami Arabs in Indonesia: From Social Hierarchy to Islamic Doctrine", Journal of Indonesia Islam 11(1): 1-28.

Slama, Martin (2005). "Indonesian Hadhramis and the Hadhramaut: An Old Diaspora and Its New Connections", Antropologi Indonesia 29: 107-113.

Smith, William G. Clarence (1997). "Hadhramaut and the Hadhrami in the Modern Colonial Era: An Introductory Survey", Ulrike Freitag dan William G. Clerence Smith (eds.), Hadhrami Traders, Scholars, and Statesmen in Indian Ocean, 1750s-1960s. Leiden: Brill.

Suratmin dan Didi Kwartanada (2014). Biografi A.R. Baswedan: Membangun Bangsa Merajut Keindonesiaan. Jakarta: Kompas.

"Orang-orang di sekitar Baswedan", www.majalah.tempo/interaktif.com/id/ar sip/2008/12/15/imz/mbm.200, diakses pada 8 Agustus 2018.

"Mengenang Hoesin Bafagih dan Tonil Fatimah", Edisi 3 Juni 2018, https://majalah. tempo.co/read/155585/mengenanghoesin-bafagih-dan-tonil-fatimah, diakses pada 8 Agustus 2018. 